\title{
Piroxicam gel, compared to EMLA cream is associated with less pain after venous cannulation in volunteers
}

\author{
[Un gel de piroxicam, comparé à une crème EMLA, est associé à moins de douleur \\ après une canulation veineuse chez des volontaires]
}

Amitabh Dutta MD, Goverdhan Dutt Puri MD PhD, Jyotsna Wig MD FAMS

Purpose: To evaluate and compare the analgesic efficacy and antiinflammatory effects of topical piroxicam gel vs eutectic mixture of local anesthetic (EMLA) cream applied to the peripheral venous cannulation site in adult volunteers.

Methods: Piroxicam gel and EMLA cream were randomly applied on the dorsum of the right and left hand of ten volunteers who acted as their own control. A venous cannula was inserted (no iv infusion) and removed after one hour. Pain scores and signs of inflammation were noted at the cannulation site up to $48 \mathrm{hr}$.

Results: Pain scores with piroxicam gel were higher on cannulation and on advancement of the cannula $(P<0.05)$. Thereafter, pain scores were significantly higher with EMLA $(P<0.05)$. Blanching was present at all the peripheral venous sites treated with EMLA cream. Signs of inflammation (erythema, edema) were not more frequent with EMLA than with piroxicam $(P>0.05)$. Induration was more frequent with EMLA at six hours.

Conclusion: In volunteers EMLA cream is associated with less pain on cannulation and cannula advancement compared to piroxicam gel. Topical application of piroxicam gel before peripheral venous cannulation alleviates pain and, possibly, inflammation in the period subsequent to cannulation itself.

Objectif : Évaluer et comparer l'efficacité analgésique et les effets anti-inflammatoires d'un gel de piroxicam topique et d'une crème d'un mélange eutectique d'anesthésique local ( EMLA) appliqués autour du site d'une canulation veineuse chez des adultes volontaires.

Méthode : Le gel de piroxicam ou la crème EMLA ont été appliqués, aléatoirement, au dos des mains droite et gauche de dix volontaires qui étaient leur propre témoin. Une canule veineuse a été insérée (sans perfusion iv) et enlevée une heure plus tard. Les scores de douleur et les signes d'inflammation ont été notés au site de canulation pendant une période allant jusqu'à $48 \mathrm{~h}$.

Résultats : Les scores de douleur ont été plus élevés avec le gel de piroxicam pendant la canulation et la poussée de la canule ( $P<$ 0,05). Par la suite, les scores de douleur ont été significativement plus élevés avec le EMLA $(P<0,05)$. La blancheur était présente à tous les sites veineux périphériques traités avec la crème EMLA. Les signes d'inflammation (érythème, œdème) étaient comparables avec les deux médicaments $(P>0,05)$. L'induration a été plus fréquente avec le EMLA à six heures.

Conclusion : Chez des volontaires, la crème EMLA est associée à moins de douleur, que le gel de piroxicam, au site de canulation et pendant la poussée de la canule. L'application topique de gel de piroxicam avant la canulation veineuse atténue la douleur et, possiblement, l'inflammation après la canulation elle-même.

$\mathrm{P}$ AIN upon venous cannulation continues to be a shortcoming with respect to the smooth initiation of anesthesia. In addition, patients may continue to have pain and discomfort at the cannulation site even after removal of the cannula. It is one of the common problems at the end of the day in surgical inpatients and constitutes an important complaint in outpatients after discharge, adding to morbidity. Local inflammation at the cannulation site is one of the mechanisms of pain. The incidence of peripheral venous thrombophlebitis

From the Department of Anaesthesia and Intensive Care, Postgraduate Institute of Medical Education and Research, Chandigarh, India. Address correspondence to: Dr. G.D. Puri, Department of Anaesthesia and Intensive Care, PGIMER, Chandigarh-160012, India.

Phone: 91-172-549717; Fax: 91-172-744401; E-mail: gdpuri007@hotmail.com Submitted July 8, 2002.

Ist revision submitted February 20, 2003.

Accepted for publication April 30, 2003. 
(PVT) is $\mathbf{1 0 - 5 7 \%}$ in patients with peripheral $i v$ lines. ${ }^{1}$ Payne-James et al. described that topical non-steroidal anti-inflammatory drugs (NSAIDs) prevent PVT, but they did not study pain scores specifically. ${ }^{2}$

Local anesthetics in one form or the other are commonly employed to overcome pain on cannulation. ${ }^{3}$ Apart from the benefit of rapidity of onset and effective pain relief, the use of local anesthetic agents is associated with a number of disadvantages, such as pin-prick pain on lidocaine $s c$ infiltration ${ }^{4}$ and blanching of the skin and vasoconstriction following the topical application of eutectic mixture of local anesthetic (EMLA) cream. ${ }^{5}$ These agents do not seem to have any effect on subsequent inflammation. Topical NSAIDs, by virtue of their capacity to inhibit prostaglandin synthesis are expected to provide analgesia and decrease the inflammatory response to cannulation. Smith et al. found that topical ibuprofen did not alleviate pain secondary to venous cannulation, but they did not study its effect on inflammation. ${ }^{4}$ Topical piroxicam, a long-acting NSAID $^{6}$ has been used as an adjuvant for postoperative analgesia in patients undergoing inguinal hernia repair. ${ }^{7}$

We evaluated the efficacy of topical piroxicam to prevent pain during and after venous cannulation and subsequent inflammation in adult volunteers.

\section{Methods}

After Ethics Committee approval and written informed consent from the subjects, a prospective and randomized study was conducted in ten healthy volunteers who acted as their own control. Volunteers belonged to either sex, were $20-60 \mathrm{yr}$ of age and American Society of Anesthesiologists physical status I or II. Subjects with asthma, NSAID allergy, chronic NSAID intake, any psychiatric disease, alcohol or drug dependence and with any local skin condition were excluded from the study.

A vein was marked on the dorsum of both hands. Piroxicam gel (Cipla, Ahmedabad, India) was applied on one hand and EMLA cream on the other hand (Astra Pharmaceuticals, NSW, Australia) of each subject based upon a computer generated random number. It was then covered with an occlusive dressing (Tegaderm, 3M Health Care, St. Paul, MN, USA) and a gauze bandage. The area of skin covered with gel $(3.8 \mathrm{~cm} \times 1.9 \mathrm{~cm})$ and the amount of topical drug preparation $(2 \mathrm{~g})$ were standardized. Volunteers were blinded to the gel applied. The gel was wiped off with an alcohol swab before cannulating the vein. Only successful cannulations at the first attempt with a $20-\mathrm{G}$ venous cannula (Venflon, Ohmeda, BOC Ohmeda, $\mathrm{AB}$, Sweden) entered the study. A single and dedicated observer unaware of the gel applied recorded the
TABLE I Visual analogue scale scores [median (range)] on cannulation and up to $48 \mathrm{hr}$

\begin{tabular}{lll}
\hline Time & $\begin{array}{l}\text { Eutectic mixture } \\
\text { of local anesthetic }\end{array}$ & Piroxicam \\
\hline On cannulation & $2.0(1-5)$ & $4.5(3-8)^{* *}$ \\
Cannula advancement & $2.0(1-3)$ & $3.5(1-7)^{*}$ \\
$1 \mathrm{hr}$ & $2.5(1-4)$ & $2.5(1-4)$ \\
$6 \mathrm{hr}$ & $3.5(1-5)^{* *}$ & $1.5(1-3)$ \\
$12 \mathrm{hr}$ & $4.0(1-5)^{* *}$ & $1.5(1-3)$ \\
$24 \mathrm{hr}$ & $4.0(1-7)^{* *}$ & $1.0(1-2)$ \\
$48 \mathrm{hr}$ & $3.0(1-6)^{*}$ & $1.0(1-2)$ \\
\hline
\end{tabular}

${ }^{*} P<0.05 ;{ }^{*} P<0.01$; Wilcoxon sum rank test.

pain scores as marked by subjects on a visual analogue scale (VAS) $1-10 \mathrm{~cm}(1=$ no pain, $10=$ worst possible pain). In addition, the observer rated local skin condition (blanching, erythema, induration, edema) at predetermined intervals. Cannulation was attempted one hour following application of the gel. The cannula was removed after one hour and local compression with pressure gauze lasted for $30 \mathrm{~min}$.

VAS scores on cannulation, during cannula advancement and at regular intervals over the next 48 hr were compared using Wilcoxon rank sum test with continuity correction. Skin condition between the two drugs was compared using Pearson's Chi squared test with Yates' continuity correction. A $P<0.05$ was considered significant. A difference of $2 \mathrm{~cm}$ on the VAS to assess pain was considered significant. To detect this difference with a statistical power of $80 \%$ or more we calculated that we would need ten subjects.

\section{Results}

VAS scores for pain on venous cannulation, during cannula advancement and at regular intervals over the subsequent $48 \mathrm{hr}$ are summarized in Table I. Pain scores were significantly higher with piroxicam on cannulation $(P<0.01)$ and with cannula advancement $(P<0.05)$. Conversely, the scores were significantly higher with EMLA at six, 12, 24 and $48 \mathrm{hr}$ intervals $(P<0.01)$.

Skin condition i.e., blanching, erythema, induration and edema, and their overall frequency at various intervals are presented in Table II. All subjects exhibited blanching with EMLA at the time of cannulation as compared to none in the piroxicam group. Blanching was still present in $50 \%$ of the volunteers at six hours.

Occurrence of erythema and edema with EMLA or with piroxicam was not different. Induration was more frequent with EMLA at six-hour interval. 
TABLE II Skin condition up to $48 \mathrm{hr}$

\begin{tabular}{|c|c|c|c|}
\hline Skin condition & $\begin{array}{l}\text { Time interval } \\
\text { of local anesthetic }\end{array}$ & Eutectic mixture & Piroxicam \\
\hline \multirow{6}{*}{ Blanching } & OC & $10^{*}$ & 0 \\
\hline & $1 \mathrm{hr}$ & $10 *$ & 0 \\
\hline & $6 \mathrm{hr}$ & $5^{*}$ & 0 \\
\hline & $12 \mathrm{hr}$ & 1 & 0 \\
\hline & $24 \mathrm{hr}$ & 0 & 0 \\
\hline & $48 \mathrm{hr}$ & 0 & 0 \\
\hline \multirow[t]{6}{*}{ Erythema } & OC & 0 & 0 \\
\hline & $1 \mathrm{hr}$ & 3 & 2 \\
\hline & $6 \mathrm{hr}$ & 6 & 2 \\
\hline & $12 \mathrm{hr}$ & 7 & 2 \\
\hline & $24 \mathrm{hr}$ & 6 & 1 \\
\hline & $48 \mathrm{hr}$ & 4 & 0 \\
\hline \multirow[t]{6}{*}{ Edema } & OC & 0 & 0 \\
\hline & $1 \mathrm{hr}$ & 4 & 2 \\
\hline & $6 \mathrm{hr}$ & 6 & 4 \\
\hline & $12 \mathrm{hr}$ & 6 & 3 \\
\hline & $24 \mathrm{hr}$ & 3 & 2 \\
\hline & $48 \mathrm{hr}$ & 1 & 1 \\
\hline \multirow[t]{6}{*}{ Induration } & OC & 0 & 0 \\
\hline & $1 \mathrm{hr}$ & 5 & 1 \\
\hline & $6 \mathrm{hr}$ & $5^{*}$ & 0 \\
\hline & $12 \mathrm{hr}$ & 3 & 2 \\
\hline & $24 \mathrm{hr}$ & 1 & 2 \\
\hline & $48 \mathrm{hr}$ & 0 & 1 \\
\hline
\end{tabular}

$\mathrm{OC}=$ on cannulation. ${ }^{*} P<0.05 ;$ Pearson's Chi squared test.

\section{Discussion}

The emergence of outpatient surgery has underlined the importance of complications like pain, postoperative nausea and vomiting, shivering, myalgia and their contribution towards overall patient morbidity. ${ }^{8}$ Pain upon venous cannulation has been the focus of few studies. ${ }^{4}$ Pain and/or discomfort at the cannulation site is one of the common complaints following surgery in inpatients. For outpatients undergoing minor surgical procedures, protracted pain at the cannulation site may be important. NSAIDs act as analgesic and anti-inflammatory agents and their utility in providing analgesia and prevention of thrombophlebitis has been reported earlier. ${ }^{2,4}$ We chose topical piroxicam, a long-acting NSAID $^{9}$ to alleviate pain on cannulation and inflammation after venous cannulation.

Piroxicam gel was less effective in preventing pain on cannulation and on advancement of the venous cannula but was associated with a lesser incidence of skin induration and subsequent pain compared to EMLA. The vasoconstrictive effect of EMLA at the time of cannulation might be responsible for blanching., ${ }^{9,10}$
Blanching was present in all patients at the time of venous cannulation. Extravasation of blood in the surrounding tissue following decannulation may also contribute to inflammation. When the vasoconstrictive effects of EMLA wear off, there is a generalized local vasodilation, which may lead to erythema and swelling. In our study, EMLA treated hands were more painful over the $48 \mathrm{hr}$ following venous cannulation.

Our study shows the advantageous analgesic effects of topical piroxicam in the period subsequent to the cannulation whereas the reduction of incidence of inflammatory skin signs was inconclusive. This warrants a larger study sample to substantiate clinical significance. Though inclusion of a placebo control would have better highlighted the analgesic efficacy of local piroxicam gel at the cannulation site, we felt it was not justified in volunteers. Although piroxicam did not fare well as compared to EMLA cream in decreasing pain during cannulation and cannula advancement, the advantageous analgesia profile of topically applied piroxicam in the period following cannulation may prove beneficial in adult outpatients as well as inpatients.

\section{References}

1 Nystrom B, Larsen SO, Dankert J, et al. Bacteraemia in surgical patients with intravenous devices: a European multicentre incidence study. The European Working Party on Control of Hospital Infections. J Hosp Infect 1983; 4: 338-49.

2 Payne-James JJ, Bray MJ, Kapadia S, Rana SK, Mcswiggan D, Silk DBA. Topical non-steroidal antiinflammatory gel for the prevention of peripheral vein thrombophletitis. A double-blind, randomised, placebo-controlled trial in normal subjects. Anaesthesia 1992; 47: 324-6.

3 Irsfeld $S$, Klement W, Lipfert P. Dermal anaesthesia: comparison of EMLA cream with iontophoretic local anaesthesia. Br J Anaesth 1993; 71: 375-8.

4 Smith AJ, Eggers KA, Stacey MRW. Topical ibuprofen for skin analgesia prior to venepuncture. Anaesthesia 1996; 51: 495-7.

5 Manner T, Kanto J, Iisalo E, Lindberg R, Viinamaki O, Scheinin $M$. Reduction of pain at venous cannulation in children with a eutectic mixture of lidocaine and prilocaine (EMLA® cream): comparison with placebo cream and no local premedication. Acta Anaesthesiol Scand 1987; 31: 735-9.

6 Insel PA. Analgesic-antipyretic and antiinflammatory agents and drugs employed in the treatment of gout. In: Gilman AG, Hardman JG, Limbird LE, Molinoff PB, Ruddon RW (Eds.). Goodman and Gilman's, The Pharmacological Basics of Therapeutics, 9th ed. New York: McGraw Hill; 1996: 617-57. 
7 O'Hanlon JJ, McCleane G, Muldoon T. Preoperative application of piroxicam gel compared to a local anaesthetic field block for postoperative analgesia. Acta Anaesthesiol Scand 1996; 40: 715-8.

8 van Vlymen JM, White PF. Outpatient anesthesia. In: Miller RD (Ed). Anesthesia, 5th ed. Philadelphia: Churchill Livingstone; 2000: 2213-40.

9 De Jong PC, Verburg MP, Lillieborg S. EMLA® cream versus ethyl-chloride spray: a comparison of the analgesic efficacy in children. Eur J Anaesthesiol 1990; 7: 473-81.

10 Hallen B, Carlsson P, Uppfeldt A. Children study of a lignocaine-prilocaine cream to relieve the pain of venepuncture. Br J Anaesth 1985; 57: 326-8.

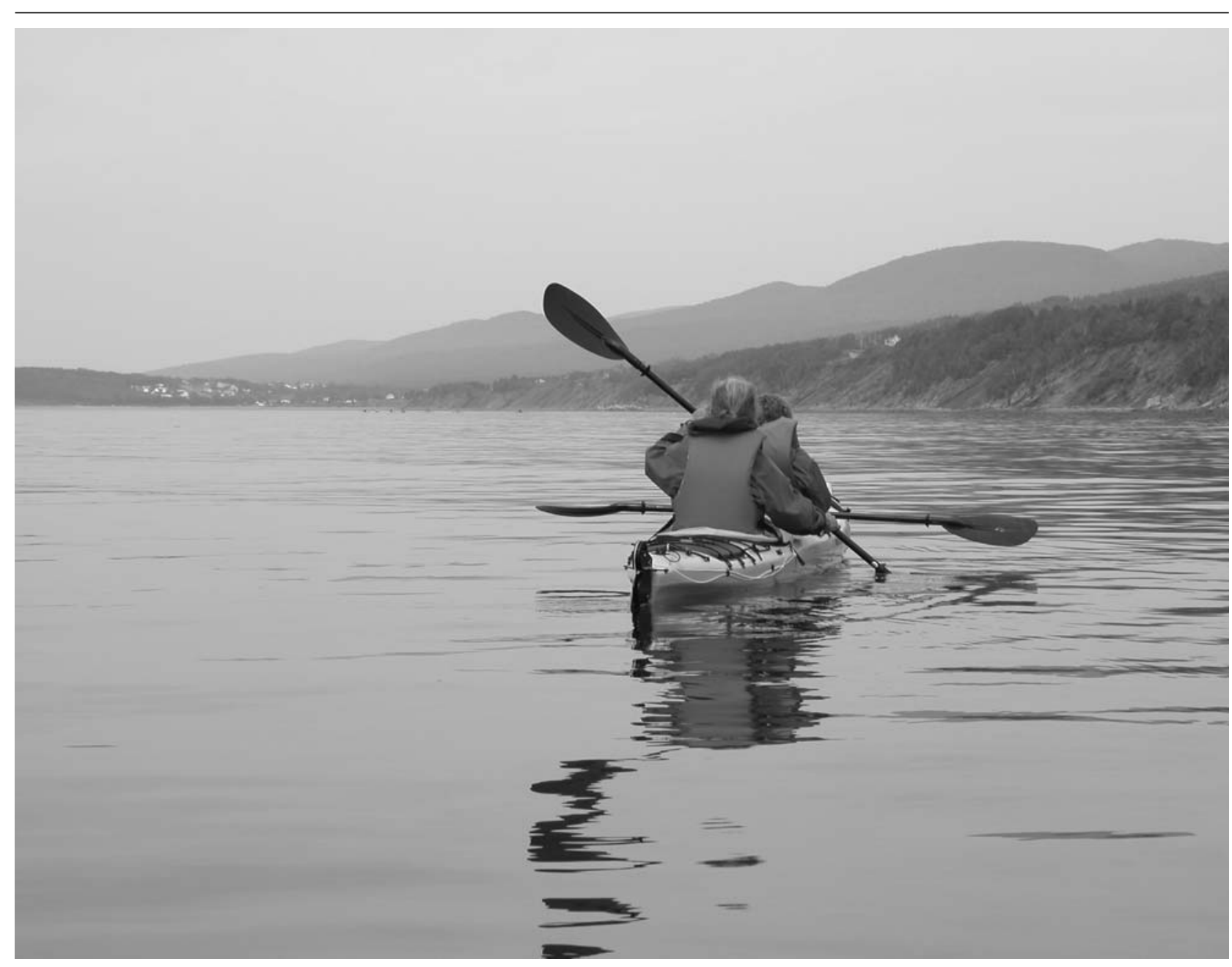

Calm Waters 